maps compiled by $\mathrm{Dr}$ J. C. Briden (University of Leeds), Dr A. G. Smith and G. E. Drewry (University of Cambridge) and distributed to contributors before the meeting. These maps showed the inferred latitude and longitude of the present continents at various intervals during the Phanerozoic.

In introducing the maps, Drs Briden and Smith explained that they had been compiled from published information on seafloor spreading, geometric fit and palaeomagnetic data. It had been possible to use this information with some confidence to wind up the oceans back to the Permian and create a "Pangea". For earlier periods, however, it had been necessary to break up the existing continents. The criteria for doing this were obscure and the palaeography was thus more speculative.

Methods of study of biological distribution were discussed by five contributors. Professor P. H. A. Sneath (University of Leicester) examined how far the degree of contiguity of land areas might be assessed from the dissimilarity of their biotas. Apart from physical and climatic barriers to migration, the timing of the radiative evolution of a taxon relative to continental drifting, and its mobility since then, affected its present distribution. An analysis of the dissimilarity of genera of conifer and notostracan crustacea correlated well with the present distribution although the short biotic distance between the conifers of the southern hemisphere was a relic of past palaeogeography.

Professor F. J. Vine (University of East Anglia) presented a new method for pole prediction from a limited amount of latitude dependent data by fitting a fourth degree polynomial for points on a global grid of trial "north poles". A confidence area for the predicted pole was then contoured from the grid. This method accurately predicted the present north pole from present faunal distribution. When applied to data for Permian brachiopods plotted on the present world map it gave several "north poles". The brachiopod data and also Permian palaeomagnetic data plotted on the Briden-Smith Permian map predicted a "north pole" about $20^{\circ}$ along the $0^{\circ}$ meridian suggesting that the map may need modification.

Dr A. Hallam (University of Oxford) analysed some patterns of faunal distribution through time and showed how these may relate to plate tectonics. Convergence in degree of resemblance between two land faunas (for example, Africa and Eurasia) may be complemented by the divergence of adjacent marine faunas (Mediterranean and Indo-Pacific). Disjunct endemism was illustrated by late Palaeozoic fossils on the present southern continents and by the Lower Jurassic bivalve Weyla, now

fossil in western North America, Mediterranean and East Africa.

The distribution of Mesozoic and Tertiary organisms was next discussed. The history of African mammals was reviewed by Drs R. J. G. Savage and S. G. Coryndon (University of Bristol). The mid Tertiary collision of Africa and Eurasia was clearly correlated with the spread of previously African endemics, notably proboscideans and sirenians, and the enrichment of African faunas from Asian stocks. Dr F. C. Dilley (BP, Sunbury-on-Thames) showed how the essentially tethyan larger foraminifera repeatedly spread to central and western America, Madagascar and Australasia in spite of ocean spreading. On the other hand Dr A. G. Coates (George Washington University) described the increasing provinciality of hermatypic corals, nerineid gastropods and rudist bivalves in the Caribbean, Mediterranean and Middle East which could be correlated with the opening of the central Atlantic and the closing of Tethys. Mesozoic floras plotted by Dr P. D. W. Barnard (University of Reading) on the Briden-Smith maps seemed to be dependent on latitude although for the Lower Triassic there was no evidence for any floras within the tropics. Mr N. F. Hughes (University of Cambridge) considered that the distribution of conifers, early angiosperms and the dispersed spores Classopollis and Normapolles on the relevant BridenSmith maps showed some dependence on latitude and could be useful in assessing past climates.

\title{
Insulin Release in Laboratory Diabetes
}

THere are now known to be a very wide variety of syndromes involving experimental diabetes in animals. Some of these are relatively bizarre in type, such as the diabetes induced by a change of diet in the sand rat, but most often the type of diabetes in such syndromes is marked by obesity and relative mildness. In but a few of these diseases has the defect been adequately characterized, and the immediate relevance of these conditions to human diabetes is far from clear.

In next Wednesday's Nature New Biology (January 19), Larkins and Martin report their observations on the responsiveness of beta cells in the islets of Langerhans of New Zealand obese mice to various agents. Neither glucose, the sulphonylurea tolbutamide nor glucagon were effective in promoting insulin release from the beta cells in such animals. By contrast, arginine was a very potent agent for insulin release-much more so than in control mice. Larkins and Martin suggest that the inability of these animals to respond to glucose is responsible for their diabetic state, and
Finally, Palaeozoic distributions were considered in relation to the more speculative Palaeozoic maps. Professor H. B. Whittington and Dr C. P. Hughes (University of Cambridge) and Professor A. Williams (Queen's University, Belfast), in discussing Ordovician trilobites and brachiopods respectively, ascribed decreasing provinciality (highlighted in mid-Caradocian times) to the closing of the Proto-Atlantic. Dr W. G. Chaloner (University College, London) contrasted the uniformity of the Lower Carboniferous flora with the Euamerian, Angara, Cathaysia and Gondwana floras developed by the Lower Permian. These floral regions showed some dependence on latitude when plotted on the Briden-Smith map but the boundary between the Angara and Cathaysia floras lay oblique to latitude. Low provinciality was apparent in the Silurian although Drs L. R. M. Cocks (British Museum (Natural History) ) and W. S. Mckerrow (University of Oxford) were able to distinguish a South AmericanWest African Clarkeia fauna and, in the late Silurian, a Nearctic-north Asian Atrypella fauna which suggested the close proximity of these areas. The distribution of Devonian goniatites (Professor M. R. House, University of Hull) showed a generalized tropical distribution on the Briden-Smith map but suggested that Africa and eastern North America were adjacent. Carboniferous goniatites (Dr F. Hodson, University of Southampton), although cosmopolitan, also showed a broad tropical distribution except for those of east Asia. that the hyperinsulinism which characterizes them is presumably related to effects of amino-acids, perhaps derived from the diet, on the beta cell. The authors also comment that a similar situation may exist in the foetal islet which is known to be much more responsive to amino-acids than to glucose.

The significance of these observations for a fuller understanding of the origin of human diabetes is, however, much less apparent. Thus, although a defect in the mechanism of insulin secretion has been incriminated in the poor insulin response of some close relatives of diabetics, its importance in the development of the fully manifest disease is very obscure, as has been emphasized by Pyke and his colleagues (Brit. Med. J., 4, 694; 1970). Moreover, many cases of diabetes are absolutely deficient in insulin from the outset. Nevertheless, the results of Larkins and Martin are interesting enough to suggest that further metabolic studies of a detailed kind should be undertaken on the beta cells in other types of laboratory diabetes. 